\title{
CODE OF BEST AGRICULTURAL PRACTICES: GENERAL CHARACTERISTICS, DISADVANTAGES, WAYS OF IMPROVEMENT
}

\author{
T.S. NOVAK, PhD (Law), Associate Professor, \\ Associate Professor of Department of the Agricultural, Land and \\ Environmental Law \\ to the name of academician V.Z. Yanchuk, \\ National University of Life and Environmental Sciences of Ukraine \\ E-mail: tomanovak1980@gmail.com \\ V.O. MELNYK, PhD (Law), \\ Assistant of the Department of Civil Law Disciplines, \\ Bila Tserkva National Agrarian University \\ E-mail: viktoriia.melnyk@ukr.net
}

Summary. The article provides a scientific and theoretical analysis of the Draft Code of Best Agricultural Practices' content and its significance for the legal support of ecologization of agriculture in Ukraine.

We have studied the content of the Draft Code of Best Agricultural Practices and the Draft Code of Proper Agricultural Practice. It was identified the deficiencies in the wording of the scope of these Draft Codes. It is also proposed to extend the Draft Code of Best Agricultural Practices' content to all agricultural producers without imposing any restrictions. It is noted that in the text of the Draft Code of Best Agricultural Practices, it is mandatory to enshrine the provision on voluntary application (based on paragraph 1 of Article 4 of Council Directive 91/676 / EEC on the protection of waters against pollution by nitrates from agricultural sources of 12.12.1991). Also, we have identified the shortcomings of the provisions of the draft Codes regarding land use management regulation, including the use of the crop rotation system. It is concluded that it is inexpedient to duplicate in the Draft Code of Best Agricultural Practices the legislation governing the organization of crop rotations. It is proposed to limit the indication to the relevant regulations. It is concluded that in parallel with the implementation of the Draft Code of Best Agricultural Practices, work should be carried out to implement the cross-compliance approach in Ukraine. This will motivate agricultural producers to comply with the Code of Best Agricultural Practices provisions and contribute to agriculture's ecologization.

Keywords: agriculture, Code of Best Agricultural Practices, legal support, ecologization of agrarian activities, nitrates, mineral fertilizers, soil 


\section{Introduction.}

In Ukraine, the issue of ecologization of agricultural activities is becoming increasingly acute and relevant, because in market conditions, when businesses in the agricultural sector in the first place put economic benefits, maximizing profits, there is the neglect of environmental requirements, which in turn leads to rapid deterioration ecological situation. Agriculture is one of the biggest polluters of the environment. It is typical for the whole world, not only for our state. The most damaging impact of agricultural activities has on soils (the contribution of this industry to the overall pollution and degradation of soils is determined at more than $50 \%$ ), surface water (40-50\%), groundwater (about 30 $\%)$ («Ecologization of sectors of the economy...»). Agriculture itself is the leading polluter of water resources with nitrates, and in recent years there has been a steady deterioration. According to official data as of 2016 in Ukraine, the share of drinking water samples taken from decentralized rural sources of drinking water supply, which exceeded the permissible content of nitrates, was: for public wells -13.1 $\%$, for the individual $-24.7 \%$. The same indicators as of 2019 were already $39 \%$ and $31 \%$, respectively (National Report, 2019: 73). To improve the situation and achieve a balance of interests, the world community is actively working towards harmonizing agricultural and environmental policies, which is reflected in international law. Ukraine is also joining this process, forming the appropriate domestic legal field. Currently, in pursuance of Art. 4 of Council Directive 91/676/ EEC concerning the protection of waters against pollution caused by nitrates from agricultural sources of 12 December 1991 ( On the Protection of Waters Against Pollution by Nitrates»), work is under way to develop such an important document (in the context of preventing the negative impact of agricultural activities on the environment) as the Code of Best Agricultural Practices. In turn, the basis for the formation of its content should be scientific research results, which determine this article's relevance.

\section{Analysis of recent researches and publications.}

A study of the source base shows that currently, scientists, as a rule, touch upon the issues of legal regulation of ecologization of agriculture in the context of sustainable development of rural areas or in the research of ecological and legal direction (among them O.V. Hafurova, M.A. Deinega, V M. Ermolenko, N.R. Kobetska, T.V. Kurman, N.O. Martynova, S.I. Marchenko, V.V. Nosik, N.M. Obiyukh, A.K. Sokolova and others). Despite the positive practice of applying the Code of Proper Agricultural Practice globally, there are no separate studies in modern legal science devoted to analyzing its significance for content (indirectly, this issue was touched upon by O.V. Hafurova (Hafurova, 2020: 41-49). Therefore, several issues need to be studied.

The article's purpose is a scientific and theoretical analysis of the content of the Draft Code of Best Agricultural Practices and its significance for the ecologization of agriculture in Ukraine.

\section{Results.}

At the outset, we note that the need to develop a document that would define the environmental requirements for agricultural activities was enshrined in the State Target Program for the development of Ukrainian villages for the pe- 
riod up to 2015, approved by the Cabinet of Ministers of Ukraine's resolution № 1158 from 19.09.2007. In paragraph 14 of this program, it was planned to develop a Draft National Code of Sustainable Agriculture to ensure basic agri-environmental requirements and standards. The same norm proposed to establish compliance with the National Code of Sustainable Management as one of the mandatory conditions for producers to receive budget support. However, the development of the considered document was not included in the State Program implementation's tasks and measures. The performers, deadlines, sources, and amounts of funding also remained unclear.

As a result, the specialists of the Institute of Economics and Forecasting of the National Academy of Sciences of Ukraine developed only the concept of the National Code of Sustainable Agricultural Management. According to the developers, it should have set requirements for preventing soil erosion, changes in its mechanical composition and structure; application of resource-saving technologies; observance of crop rotations; preservation of natural centers among the fields; storage, use of fertilizers, plant protection products. The Code was also established: norms for maintaining crops and livestock by agricultural enterprises, mandatory periodic soil analysis, and development of fertilizer application plan (Zubar, 2017: 117). It was proposed to adopt such a Code in the form of a law with subsequent amendments to existing regulations governing relations in the areas of use and protection of water resources, soils, plants, etc. In our opinion, the proposal to adopt the National Code of Sustainable Agriculture as a law of Ukraine is not successful because, for the vast majority of issues that this act should regulate, there is al- ready legal support. It would be more logical to focus on improving the current legislation to establish environmental requirements for agricultural activities, post-resource legislation.

In addition to the mentioned National Code of Sustainable Agriculture, on October 25, 2017 the Cabinet of Ministers of Ukraine approved by the resolution № 1106 , due to the mentioned resolution the Draft Code of Best Agricultural Practices should be adopted due to the Action Plan for the Implementation of the Association Agreement between Ukraine, on the one hand, and the European Union, the European Atomic Energy Community, and their Member States, on the other hand.Unlike the National Code of Sustainable Agricultural Management, which was initiated by the so-called «domestic» one, the development, approval, and implementation of the Draft Code of Best Agricultural Practices is mandatory for Ukraine to fulfill the obligations undertaken when signing the Association Agreement. Namely, as we noted above, the implementation of Council Directive 91/676 / EEC of December 12, 1991, on the protection of waters against pollution caused by nitrates from agricultural sources. According to Art. 4 of Directive 1/676 / EC, Code of Proper Agricultural Practice is applied voluntarily and aim to ensure a general level of protection of waters against pollution caused by nitrates from agricultural sources. The developed code(s) must be completed within two years of notification by the country of this Directive. Ukraine should create a Code of Best Agricultural Practice by 31.12.2020 («On Implementation of the Association Agreement...»). However, as of January 2021, only: the Draft Code of Best Agricultural Practices («Draft Code of 
Best...») and the Draft Code of Proper Agricultural Practices («Draft Code of Proper...») were published. We will focus on the coverage of debatable (in our opinion) provisions of these documents.

In terms of structure, both draft codes comply with Annex II A of Directive 91/676 / EEC, which sets out a minimum list of provisions reflected in the Code of Proper Agricultural Practice. These are periods during which fertilizer application to the soil is undesirable; application of fertilizer to the soil located on steep slopes; application of fertilizer to the soil saturated with water, flooded, frozen, or snow-covered ground; conditions for applying fertilizer to the soil near watercourses; capacity and construction of manure storage tanks, including measures to prevent contamination of water from runoff and infiltration into groundwater and surface water of liquids containing manure and runoff from the storage of plant materials, such as silage; soil application procedures, including rate and uniformity of application, of mineral fertilizers and waste, which will maintain the release of nutrients into the water at an acceptable level.

Besides, the projects in question contain clauses whose inclusion is a right, not an obligation, of the Member States. They are listed in Annex II B of Directive 91/676 / EEC. These are land use management, including the use of crop rotation and the proportion of land area allocated to perennial crops compared to annual crops; maintaining a minimum amount of vegetation during (rainy) periods, which will absorb nitrogen from the soil, which otherwise will cause water pollution by nitrates; development of fertilizer application plans for each farm separately and keeping records of their use; prevention of water pollution from water runoff and groundwater movement below the reach of crop roots in irrigation systems.
The scope of the codes defined by the projects is remarkable.

Thus, the Draft Code of Best Agricultural Practices makes it mandatory for agricultural enterprises/ farms located in areas vulnerable to nitrogen contamination, as defined in the relevant register. Voluntary compliance with this Code is provided for agrarian enterprises/farms located in other areas. As O.V. Hafurova rightly points out, this provision contradicts the EU legislation (paragraph 1 of Article 4 of Directive 91/676/EEC), which enshrines the voluntary application of the Code (Hafurova, 2020: 45). It is also doubtful that the Code applies only to agricultural enterprises and farms. It does not apply to other types of legal entities and natural persons-entrepreneurs engaged in farm activities. Finally, the reference in the Code's text to the invalid Law of Ukraine «On Value Added Tax» in defining the concept of «agricultural enterprise» is incorrect.

As for the proposed scope of another project - the Draft Code of Proper Agricultural Practice, the developers propose to extend it to «agricultural producers engaged in economic activities in areas vulnerable to (accumulation) of nitrates, which are listed in the relevant register and have in land tenure and land use of more than 15 hectares of agricultural land». In our opinion, it is correct to use the term «agricultural producer» as one that covers as much as possible the subjects engaged in agricultural activities. However, we do not agree with the definition of the term «agricultural producer» in paragraph 2 of Section «General Provisions» of the Draft Code of Proper Agricultural Practice as «a legal entity, regardless of its legal form, a farm, including a family farm, an individual. an entrepreneur engaged in agricultural activities at his own or leased capacity and carries out operations to supply such

48 | ISSN 2663-1350 «ПРАВО. ЛЮДИНА. ДОВКІЛЛЯ» | «LAW. HUMAN. ENVIRONMENT» Vol. 12, № 1, 202 
activities' products»». In this wording, it does not meet the definition in the Tax Code (subparagraph 14.1.235, paragraph 14.1 of Article 14) «agricultural producer» - is «a legal entity, regardless of legal form or a natural person - an entrepreneur engaged in the production of agricultural products and breeding, rearing and catching fish in inland waters (lakes, ponds, and reservoirs) and processing it at its own or leased capacity, including self-produced raw materials on toll terms, and carries out operations for its supply». It would be more correct to limit the Draft Code of Proper Agricultural Practice to a reference to a legal act that defines the concept of «agricultural producer».

The proposed restriction on the size of land plots as a criterion for extending the Draft Code of Proper Agricultural Practice scope is controversial. Firstly, Directive 91/676 / EEC does not contain any provisions in this regard. Secondly, it is not clear to set the minimum land size in this context at 15 hectares. Thirdly, Ukraine has now chosen a course to support the development of family farms, the vast majority of which own/ use small plots of land. It should note that the prevalence in the structure of small family farms is typical for many European countries, including Poland, Greece, Italy, Austria (Markitanenko, 2018). And the effectiveness of this method of management is proven.

Summarizing the above, we propose to extend (voluntarily) the scope of the Draft Code of Best Agricultural Practices to all agricultural producers without establishing any additional criteria.

Also controversial is the content of Section VIII, «Management of Land Use, Including Crop Rotation, Their Optimal Ratio, and Maintenance of Soil Quality» of the Draft Code of Proper Agricultural Practice and similar section
VII, «Crop Rotation and Maintenance of Soil Quality» of the Draft Code of Best Agricultural Practices. First of all, it should be note (we have already mentioned above) that the inclusion of such provisions are not mandatory under Annex II B of the Directive 91/676 / EEC.

Besides, both Draft Codes in these sections contain instructions on the mandatory implementation of land management «on the organization of rational land use through the development of land management schemes and feasibility study of land use and protection of administrative-territorial units» set out in Art. Art.20, 45 of the Law of Ukraine «On Land Management» dated 22.05.2003 № 858-IV. However, the development of land management projects that provide environmental and economic justification for crop rotation and land management is governed by Art. 52 of the Law of Ukraine «On Land Management». Such projects are currently voluntary and carried out at landowners' and land users' requests. In both projects, these sections duplicate certain provisions of such as act as the Standards for the optimal ratio of crops in crop rotations in different natural economic regions («On approval of standards...»), which is impractical. It would be better to limit the reference to this document.

As for the motivation of agricultural producers to comply with the Draft Code of Best Agricultural Practices requirements in general and the requirements for crop rotation, in particular, here we support scientists who propose to introduce a cross-compliance approach in Ukraine. According to this approach, agricultural producers can count on financial support under any government programs only in compliance with agriculture's established environmental requirements (Popova, 2016: 150; Zinchuk \& Kovalchuk, 2017: 287). 


\section{Conclusions and prospects.}

Therefore, the draft Codes of Best / Proper Agricultural Practices submitted to the public need to be finalized and harmonized with the current legislation of Ukraine. The scope of their action needs to be clarified. It is mandatory to indicate their voluntary use. It is necessary to improve the provisions of projects in terms of legal regulation of crop rotation to measure soil conservation. In the proposed version, the Draft Code of Best Agricultural Practices (in the style and form of presentation of the material) is more of a guide or guidelines than a normative act.

\section{References}

1. Ekolohizatsiya sektoriv ekonomiky: silske hospodarstvo [Ecologization of economic sectors: agriculture]. Available at: http://www. ecoleague.net/pro-vel/tematychni-napriamy-diialnosti/ekolohizatsiia-sektoriv-ekonomiky/silske-hospodarstvo (in Ukrainian).

2. Natsionalna dopovid pro yakist pitnoi void i stan pitnogo vodopostannya v Ukrayini v 2019 rotsi. Ministerstvo rozvitku gromad I teritoriy Ukrayiny (2020) [National report on drinking water quality and the state of drinking water supply in Ukraine in 2019]. Ministry of Development of Communities and Territories of Ukraine. Kyiv, 351. Available at: https://www.minregion.gov. ua/napryamki-diyalnosti/zhkh/teplo-vodopostachannya-ta-vodovidvedennya/ natsionalna-dopovid/naczionalna-dopovid-pro-yakist-pytnoyi-vody-ta-stan-pytnogo-vodopostachannya-v-ukrayini-za-2019-rik/ (in Ukrainian).

3. Council Directive 91/676/EEC of 12 December 1991 on the protection of waters against pollution caused by nitrates from agricultural sources. Available at: https://www.kmu. gov.ua/storage/app/ sites/1/55-GOEEl/direkӨva-radi-91-676-ees. Pdf (in English).
4. Hafurova, O.V. (2020). Problemy vdoskonalennya zakonodavstva Ukrayiny u sferi yakosti pitnoyi vody (naprykladi implementatsiyi «nitratnoyi» dyrektyvy). Pravo. Lyudyna. Dovkillya. [Problems of Improving Ukrainian Legislation in the Sphere of Drinking Water Quality (on the example of implementation of the nitrate directive). Law. Human. Environment], 11(3): 41-49. (in Ukrainian).

5. Zubar, I. (2017). Instytutsiyne zabezpechennya orhanizatsiyi staloho zemlekorystuvannya: svitoviy dosvid ta perspektyvy $v$ Ukrayini. Ekonomika. Finansy. Menedzhment: aktual'ni pytannya nauky ta praktyky [Institutional Support of Sustainable Land Use: World Experience and Perspectives in Ukraine. Economy. Finances. Management: current issues of science and practice], 5: 109-122 (in Ukrainian).

6. Pro vykonannya Uhody pro asotsiatsiyu mizh Ukrayinoyu, z odnoho boku, ta Yevropeyskym Soyuzom, Yevropeyskym spivtovarystvom $z$ atomnoyi enerhiyi ta yikhnimy derzhavamy-chlenamy, z inshoyi storony [On implementation of the Association Agreement between Ukraine, on the one hand, and the European Union, the European Atomic Energy Community and their Member States, on the other hand]: Resolution of the Cabinet of Ministers of Ukraine of 25.10.2017 № 1106. Official Gazette of Ukraine. 2018. № 24. P. 852 (in Ukrainian).

7. Proekt Kodeksu krashchykh silskohospodarskykh praktyk [Draft Code of Best Agricultural Practices]. Available at: https://mepr. gov.ua/news/35591.html (in Ukrainian).

8. Proekt Kodeksu neobkhidnoyi silskohospodarskoyi praktyky [Draft Code of Proper Agricultural Practice]. Available at: https:// agro.me.gov.ua/ua/napryamki/fermerstvo-ta-kooperaciya/krashchi-praktiki-diyalnosti-malih-subyektiv-gospodaryuvannya (in Ukrainian).

9. Markitanenko, S. Efektyvni fermery chy neefektyvni ahrokholdynhy? [Effective Farmers or Inefficient Agricultural Hold- 
ings?]. Available at: https://latifundist. com/193-efektivn-fermeri-chi-neefektivn-agroholdingi (in Ukrainian).

10. Pro zatverdzhennya normatyviv optymalnoho spivvidnoshennya kultur v sivozminakh v riznykh pryrodno-hospodarskykh rehionakh [On approval of standards for the optimal ratio of crops in crop rotations in different natural and economic regions]: Resolution of the Cabinet of Ministers of Ukraine of 11.02.2010 № 164. Official Gazette of Ukraine. 2010. № 13. P. 613 (in Ukrainian).

11. Popova, O.L. (2016). Cross-compliance - yevropeyskyy pidkhid vzayemnoho dotrimannya zobovyazan pry nadanni derzhavnoyi pidtrymky silhospvyrobnykam. Ekonomika ta prohnozuvannya [Cross-compliance - a European Approach to Mutual Compliance with Obligations in Providing State Support to Farmers. Economics and forecasting]. 3: 148-151 (in Ukrainian).

12. Zinchuk, T.O. \& Kovalchuk, O.D. (2017). «Cross compliance» yak umova ekolohichnobezpechnoho silskoho hospodarstva YS. Orhanichne vyrobnytstvo ta prodovolcha bezpeka [«Cross compliance» as a Condition of Environmentally Friendly Agriculture in the EU. Organic production and food scurity]. Zhytomyr: ZhNAEU, 283-288 (in Ukrainian).

Т.С. Новак \& В.О. МеЛЬНИК (2021). КОДЕКС КРАЩИХ СІЛЬСЬКОГОСПОДАРСЬКИХ ПРАКТИК: ЗАГАЛЬНА ХАРАКТЕРИСТИКА, НЕДОЛІКИ, ШЛЯХИ УДОСКОНАЛЕН-

НЯ. Право. Людина. Довкілля, 12(1): 45-51. https://doi.org/10.31548/law2021.01.006

Анотація. У статті здійснено науково-теоретичний аналіз змісту Кодексу найкращих сільськогосподарських практик та його значення для правового забезпечення екологізації сільського господарства України.

Досліджено зміст проекту Кодексу кращих сільськогосподарських практик та проекту Кодексу належної сільськогосподарської практики. Виявлено недоліки в частині формулювання сфрери дії цих Кодексів. Запропоновано поширити среру дії Кодексу кращих сільськогосподарських практик на всіх сільськогосподарських товаровиробників без встановлення будь-яких обмежень. Відзначено, що в тексті Кодексу кращих сільськогосподарських практик обов'язковим $є$ закріплення положення про добровільність його застосування (на основі п. $1 \mathrm{~cm}$. 4 Директиви Ради 91/676/ЄЕС від 12.12.1991 р. про захист вод від забруднення нітратами з сільськогосподарських джерел). Визначено недоліки положень проектів Кодексів в частині регулювання управління землекористування, включаючи використання системи сівозмін. Зроблено висновок про недоцільність дублювання в Кодексі кращих сільськогосподарських практик норм законодавства, що регулює питання організації сівозмін. Запропоновано обмежитись вказівкою на відповідні нормативні акти.

Зроблено висновок, що паралельно із введенням у дію Кодексу кращих сільськогосподарських практик повинна проводитись робота щодо впровадження в Україні підходу "cross-compliance». Це дозволить мотивувати сільськогосподарських товаровиробників до виконання положень Кодексу кращих сільськогосподарських практик та сприятиме екологізації сільського господарства.

Ключові слова: сільське господарство, Кодекс кращих сільськогосподарських практик, правове забезпечення, екологізачія сільськогосподарської діяльності, нітрати, мінеральні добрива, грунт 